\title{
RISK-BASED APPROACH \\ IN THE PREVENTION OF MONEY LAUNDERING
}

\author{
Georgi Petrunov ${ }^{1}$
}

DOI: https://doi.org/10.31410/LIMEN.2019.53

\begin{abstract}
New compliance regulations developed in the past several years by international organizations for tackling money laundering emphasize the risk-based approach as a critical element in the prevention of the crime. This article elaborates on the new trends in this field. The first section looks at the main documents underlying the legal framework set in place to protect the financial system from being used for money laundering purposes. Highlighting key concepts in the selected documents, the article reveals important changes in the philosophy backing up anti-money laundering policies: from sanctioning to prevention through the application of macro and micro risk assessments. In this context, the article further discusses the requirements for businesses to follow a risk-based approach in evaluating the risk of money laundering in establishing business relationships with new customers; the need to monitor and control these relationships. Specific steps are proposed to design a comprehensive riskbased anti-money laundering program.
\end{abstract}

Keywords: Financial system, Banking, Crime.

\section{INTRODUCTION}

$I^{n}$ n today's global market, people, goods and capital move freely and quickly, which provides many opportunities for business development beyond national borders. The tendency is for continuous increase of financial flows. As reported by the European Central Bank, the number of transactions in the EU has increased many times - if at the beginning of the $21^{\text {st }}$ century there were 48 billion transactions, then in 2018 their number is already nearly 140 billion (European Central Bank, 2019). This huge movement of funds also has its challenges. One of the most significant problems that is evolving in parallel with the expansion of international business opportunities is the movement of criminal proceeds as part of the money laundering process. Criminals benefit from open borders and improved transport connections, and the rapid progress in communications and technology to almost the same extent as legal businesses, and in some areas have adapted even better (Chatterjee, 2005; Albertson \& Fox, 2012). In the massive financial flows, it is very difficult to distinguish between licit and illicit funds - an advantage that money launderers use readily. Based on this indistinguishability of financial flows, during the initial development of global processes in the economy some researchers argue that the „dirty money” flows need not be stopped because they provide much needed resources in economies, especially if the crime is committed in another country. Today, however, the international community is unanimous about the harms caused by illicit financial flows on various spheres of society. With regard to the financial system, researchers point to a number of negative effects, some of which are - the destruction of the integrity and stability of financial systems; a threat to fiscal stability; macroeconomic instability, etc. (Reuter, 2013). Along with this, the main motive for combating money laundering is the belief that „dirty money” gives enormous power to criminals, through which they not only continue to carry out and expand their criminal activities, but also enter the legal economy, and often in politics.

University of National and World Economy, Sofia, Bulgaria, boul. 8th December 
These reasons have pushed the international community to take action to counteract money laundering globally and nationally. Over the last three decades, a broad legal framework has been developed that sets out specific guidelines and requirements that countries, and in particular financial institutions and business organizations, must adhere to in the conduct of their business. The belief is that anti-money laundering (AML) measures must become an integral part of financial and non-financial institutions' corporate social responsibility policies (Simonova, 2011).

This paper outlines some of the new regulations for counteracting money laundering in the financial system, focusing on how the anti-money laundering system is changing - from a rulebased approach to a risk-based approach. The development of the global financial market and the opportunities offered for money transfers indicate that constant monitoring and evaluation are needed to be successful in combating money laundering. Therefore, in the last few European directives and in the recommendations of the Task Force on Financial Action against Money Laundering (FATF), the risk approach has been identified as the main element for effective prevention of the use of the financial system for criminal purposes.

\section{SHIFT TOWARDS RISK-BASED APPROACH IN ANTI-MONEY LAUNDERING FRAMEWORK}

The active work towards an international anti-money laundering framework began in the late 1980s. A key role played by the 1988 United Nations Convention on the Illicit Trafficking in Narcotic Drugs and Psychotropic Substances. Through it, the proceeds from the production, trafficking and trade in drugs and psychotropic substances are incriminated and a definition of money laundering is proposed, which is used in a number of international documents thereafter. The list of predicate money laundering offenses gradually begins to expand, and today in most countries, any crime from which illicit property has been acquired can be linked to money laundering.

In 1989, the Special Task Force on Financial Action against Money Laundering (FATF) was established, which, through its 40 Recommendations, set the basic standards for combating money laundering (and, later on, terrorist financing). The recommendations have been revised several times to best meet the changing conditions and different methods used by criminals to launder money. The EU has transposed these standards through its five anti-money directives so far.

The 2003 FATF Recommendations introduce a new concept for AML: a risk-based approach, which provides for the allocation of resources based on an assessment of the money laundering risk that clients and their business represent. The idea is reflected at European level through Directive of 2005 (2005/60/EC). During this period, a risk assessment is recommended to be applied in conjunction with the current rule-based approach, i.e. it is only one of the elements and numerous rules that reporting entities must follow. It is only in the 2012 Recommendations and in the subsequent Fourth Directive (EU) 2015/849 and the Fifth Directive (EU) 2018/843 that the risk-assessment approach has been taken as a leading method for counteracting money laundering. According to FATF, the risk approach allows Member States to adopt a more flexible set of measures commensurate with the nature of the risks and to apply them effectively to higher risk areas.

The rule-based approach adopted by the first two European directives focuses on imposing common rules for the investigation of a crime already committed, while the risk assessment concept aims at preventing it and preventing the flow of ,dirty money' into the economy (Costanzo, 2013). The purpose is to carry out a dynamic risk assessment, first at the macro level, and then at 
the micro level (by financial and non-financial organizations and institutions themselves), in order to respond in the most efficient way to today's rapidly changing conditions. The rule-based approach relies on the assumption that common pre-defined rules for all countries and reporting entities will cover the potential risks of money laundering. The risk-based approach challenges this notion arguing that the application of uniform rules for all leads to ineffective results (Bello \& Harvey, 2017). AML regimes must be different to reflect the particularities of the country first, especially with regard to the characteristics of the legal system and the overall risk profile (Costanzo, 2013), and then the individual business activities and business sectors (Jeans, 2016).

The Fourth European Directive (EU) 2015/849 explicitly puts forward the risk-assessment approach, aiming to enable entities to better identify, understand and mitigate money laundering risks (Ernst \& Young, 2016). The reporting entities are required to document and systematically update the risk assessments they carry out on their clients. To do this, the level of risk for the organization should be determined, the controls and information collected for customers increased, the number of people designated to fall into the category of politically exposed persons (PEPs) increased and more. The fifth Directive (EU) 2018/843 introduces new enhanced controls on virtual money and prepaid cards. The requirements for identifying the beneficial owner become much stricter. The fifth directive is to be transposed into national law by 10 January 2020. The two directives significantly increase the penalties for non-compliance in this field.

Through the emphasis on risk-assessment as the lead approach in anti-money laundering measures, a change in the philosophy informing the policies in this field is taking place - from sanctioning crimes already committed, efforts are increasingly focused on preventing and predicting the risk of criminal phenomena. This change significantly enhances the role of private business. Whereas in the beginning the state and its institutions played a decisive role in the fight against money laundering, today the private sector is one that has a very significant function in counteracting, even challenging the main role of the state (de Oliveira, 2018). It is the private actors who decide which client, transaction or operation poses a risk and which does not, what to report as suspicious of money laundering and what not (Helgesson \& Mörth, 2018).

\section{IMPLEMENTING THE RISK-BASED APPROACH}

The European Directives and the FATF Recommendations guide countries to conduct risk assessments that take into account their capacity and experience in each sector that needs to comply with money laundering requirements. Member states need to identify, evaluate and understand the risks of money laundering and take commensurate preventative measures (European Commission, 2019).

Implementing the risk-based approach for the prevention of money laundering is more complicated than the rule-based approach, where the emphasis is on compliance. The application of the risk approach is not limited to the one-off initial identification of risk for the organization concerned, but requires systematic monitoring and update of the assessment. The regime based on the risk approach entails the preparation of risk assessment at several levels - supranational, national and by the reporting entities. The first assessment is drawn up by the European Commission, the second by the national institutions responsible for implementing the legislation in this field. The national money laundering risk assessment needs to be updated on a regular basis, in order to reflect the results of the supranational risk assessment and the EC recommendations. Non-financial and financial institutions subject to anti-money laundering legislation also need to apply risk assessment in their activities, and they may also take advantage from an initial assessment at sectoral level. 
In preparing their own risk assessment, the reporting entities should take into account the existing risk factors such as client activity, country of origin and place of business, types of services offered, nature of the requested operation and transaction, etc. Based on the risk assessment, the reporting entities carry out a certain type of complex checks - simplified or extended, in order to create a client profile. Depending on the risk level - high, medium, or low - associated with a client, the amount and content of information that will be collected about a client is determined. At what intervals the information collected about the client is updated also depends on the results of the risk-based approach and the category in which the client account is placed.

The content of the program that reporting entities will need to implement in order to comply with the legal stipulations against money laundering depends to a large extent on the degree of risk - for the country as a whole and for the particular business in particular. However, there are several basic elements that such a program should include. First, it is necessary to decide who will be charged with the responsibility of enforcing the legal requirements - whether there will be a separate position / department for this or in case of a smaller company, this responsibility may be assumed by the manager. A risk-based money laundering program starts with a risk assessment of the organization concerned, which takes into account the results of national and supranational risk assessments. This step requires: drawing up a list of potential risks and risk factors; establishing clear criteria for determining the level of risk of different clients and the intervals at which to update the risk assessment; analyzing the identified risks. The next important step is to establish clear procedures that the employees need to follow for identifying clients: what information should be collected, when a simplified or expanded comprehensive check should be carried out, what are the means of establishing the origin of the funds and the actual owner, how to identify related transactions, to whom to report, when to monitor and evaluate business relationships, etc. Another element in an anti-money laundering program is the establishment of rules for the collection, archiving and disclosure of documents, data and information about clients of the organization. Rules for training and for monitoring the implementation of the legal requirements are also essential. These steps are interrelated and the quality of their implementation determines the effectiveness of the money laundering prevention program. This, of course, is not an exhaustive list of instructions, but rather guidelines, which can be modified and amended depending on the specific activity of the reporting entity and the degree of risk of money laundering related to this activity.

\section{FUTURE RESEARCH DIRECTIONS}

Despite the consensus among international money laundering organizations on the direction of development, some authors have noted (Helgesson \& Mörth, 2018) that following a risk approach as a fundamental principle in combating money laundering may be contrary to the specifics of some business areas. This contradiction, in their view, stems from the three basic assumptions on which this approach is built: responsibility of the private sector; identifiable risks by the private sector; proactive attitude by the private sector.

The first assumption implies that the primary responsibility for determining what is a risk and what is not is transferred to the reporting entities. In addition, it is assumed that the risks of money laundering can be identified and the employees of the reporting entity would, accordingly, suspend the suspicious transactions and report them. According to researchers, these requirements may conflict with the characteristics of particular professions, for example, lawyers, and the principle of confidentiality between client and lawyer. In this regard, calls are made for further research and analysis of how reporting entities - the frontline practitioners in the 
anti-money laundering system - understand the regulations and rules in this field and how they manage to put them into practice.

The observations of Levi et al. (2018) indicate that it seems to be taken for granted that the system of money laundering prevention will have a positive impact on welfare, without it being subject to an impact assessment and a cost-benefit analysis (direct and indirect) of its implementation. This does not mean that the efforts to combat money laundering do not have the desired effect; rather, what is needed is a better assessment of how the measures are implemented, analysis of the different impact they have on reporting entities, on developing countries and the various sectors; in other words, it is necessary to gather credible evidence of the effectiveness of the system. To achieve that objective, further research needs to be done and more data collected about the crime itself, in order to determine whether the adopted measures have led to a decrease in the crime rate.

\section{CONCLUSION}

Notwithstanding the questions about the effectiveness of the anti-money laundering measures, it should be noted that one of the important benefits of applying the risk assessment approach is that it allows the reporting entities to decide for themselves which aspect of their business deserves more attention. Of course, no system can detect every single risk of money laundering, but reporting entities must apply the system that is best suited to their business. The risk assessment approach is no guarantee that all questions about this crime will find answers. The approach is useful as it demonstrates that there cannot be a one-size-fits all solution and that not all reporting entities are equally vulnerable to money laundering. The risk-based approach allows to prioritize those clients, transactions and operations that are defined as riskier for money laundering. This is of particular importance today, in the context of growing amounts of information becoming available; the application of the risk-based approach is expected to gain in relevance and usefulness in the coming years.

Of great importance is the requirement to build a supranational and national risk assessment, which implies a shared understanding of the risk of money laundering among a wide range of stakeholders at different levels. In itself, having consensus on an important issue like money laundering, which is a threat to every country in the world, is an important prerequisite for effectively combating crime and protecting the financial system from misuse.

\section{ACKNOWLEDGMENT}

This paper is result of the author’s work in frame of research project № NID NI-10/2018: "Money Laundering from Human trafficking" financed by University of National and World Economy, Sofia.

\section{REFERENCES}

Albertson, K. \& Fox, C. (2012). Crime and Economics. London: Routledge.

Bello, A. \& Harvey, J. (2017). From a risk-based to an uncertainty-based approach to anti-money laundering compliance. Security Journal, 30(1), 24-38.

Chatterjee, J. (2005). The Changing Structure of Organized Crime Groups. Ottawa: Royal Canadian Mounted Police.

Costanzo, P. (2013). The risk-based approach to anti-money laundering and counter-terrorist financing in international and EU standards: what it is, what it entails. In B. Unger \& D. van 
der Linde (Eds.). Research Handbook on Money Laundering (pp. 349-367). Cheltenham, UK: Edward Elgar Publishing.

de Oliveira, I. S. (2018). The governance of the financial action task force: an analysis of power and influence throughout the years. Crime, Law \& Social Change, 69(2), 153-172.

Directive 2005/60/EC of the European Parliament and of the Council of 26 October 2005 on the Prevention of the use of the financial system for the purpose of money laundering and terrorist financing, OJ L 309/15, 25.11.2005.

Directive (EU) 2015/849 of the European Parliament and of the Council of 20 May 2015 on the prevention of the use of the financial system for the purposes of money laundering or terrorist financing, amending Regulation (EU) No 648/2012 of the European Parliament and of the Council, and repealing Directive 2005/60/EC of the European Parliament and of the Council and Commission Directive 2006/70/EC, OJ L 141/73.

Directive 2018/843 of the European Parliament and of the Council of 30 May 2018 on amending Directive (EC) 2015/849 on the Prevention of the use of the financial system for the purpose of money laundering and terrorist financing and amending Directive 2009/138/EO and 2013/36/EC.

Ernst \& Young. (2016). Wind of change: Risk Assessment Anti-Money Laundering, Countering Terrorism Financing, Application of International Sanctions. Available at: https://www.apcf.ro/ static/files/EY_Romania_Wind_of_Change_AML_Risk_Assessment.pdf.

European Central Bank. Number of payment transactions involving non-MFIs. Available at: http://sdw.ecb.europa.eu/reports.do?node=1000001386.

European Commission. (2019). Commission Staff Working Document accompanying the document Report from the Commission to the European Parliament and The Council on the assessment of the risk of money laundering and terrorist financing affecting the internal market and relating to cross-border activities Brussels, 24.7.2019, SWD (2019) 650 final.

Helgesson, K. S. \& Mörth, U. (2018). Client privilege, compliance and the rule of law: Swedish lawyers and money laundering prevention. Crime, Law \& Social Change, 69(2), 227-248.

Jeans, N. (2016). Risk-based approach to KYC. Thomson Reuters. Available at: https://blogs. thomsonreuters.com/answerson/kyc-risk-based-approach/.

Levi, M., Reuter, P. \& Halliday, T. (2018). Can the AML system be evaluated without better data? Crime, Law \& Social Change, 69(2), 307-328.

Reuter, P. (2013). Are Estimates of the Volume of Money Laundering either Feasible or Useful? In: B. Unger \& D. van der Linde (Eds.). Research Handbook on Money Laundering (pp. 224-231). Cheltenham, UK: Edward Elgar Publishing.

Simonova, A. (2011). The risk-based approach to anti-money laundering: problems and solutions. Journal of Money Laundering Control, 14(4), 346-358. https://doi. org $/ 10.1108 / 13685201111173820$.

The Financial Action Task Force (FATF). The FATF Recommendations 2003 (October 2004). Available at: http://www.fatfgafi.org/media/fatf/documents/FATF\%20Standards $\% 20-\% 20$ 40\%20Recommendations\%20rc.pdf.

The Financial Action Task Force (FATF). The FATF Recommendations 2012 (February 2012). Available at: http://www.fatfgafi.org/media/fatf/documents/recommendations/pdfs/FATF_ Recommendations.pdf.

United Nations Convention Against Illicit Traffic in Narcotic Drugs and Psychotropic Substances, (Vienna, 1988). Available at: https://www.unodc.org/pdf/convention_1988_en.pdf. 